\title{
Ambivalence and Discourse in Alien Nation
}

\author{
William O. Deaver, Jr. ${ }^{1}$
}

This study examines the 1988 film Alien Nation, detailing the fictitious account of racism and bigotry in the USA toward a group of extraterrestrials. This account is analogous to attitudes toward ethnic minorities. It incorporates theories from Mikhail Bakhtin and Paolo Freire to show how the film upholds negative attitudes toward minorities. [Article copies available for a fee from The Transformative Studies Institute. E-mail address: journal@transformativestudies.org Website: http://www.transformativestudies.org (C2016 by The Transformative Studies Institute. All rights reserved.]

KEYWORDS: Alien Nation, Alienation, Racism, Violence, Sexism, Police Brutality.

The 1988 film Alien Nation depicts the immigrant experience in historical and contemporary America where these groups come to comprise minorities who feel not only the social ostracism of alienation, but also that they form a nation within a nation because of their different linguistic traits, physical appearances, and social customs. Furthermore, the title, in all its ambivalence, emphasizes this rift since the word "alienation" has been split in two; hence, despite affirmative action policies, while assimilation occurs to some degree, social acceptance does not-not in the film, and not in reality. Because of this scission minorities must seek bonding through solidarity within their own ethnic group, forming enclave communities, which upholds a systemic bondage from which they must continually strive to free themselves since the majority denies them positions of true authority as well as the respect that they deserve.

\footnotetext{
${ }^{1}$ William O. Deaver, Jr., Ph.D., is a professor of Spanish at Armstrong State University in Savannah, Georgia. He holds a B.A. in English and an M.A. in Spanish from the University of Virginia as well as a Ph.D. in Spanish from Florida State University. He has published numerous articles on Spanish and Latin American literature. Address correspondence to: William O. Deaver, Jr., Armstrong State University; e-mail: bill.deaver@armstrong.edu.
} 